\title{
BUILDING EFL STUDENTS’ SELF-CONFIDENCE, MOTIVATION, and ABILITY IN LISTENING ENGLISH 2.0
}

\author{
Hastowohadi ${ }^{1}$ Ruston Kumaini ${ }^{2}$ \\ Untag Banyuwangi \\ hastowohadi@gmail.com \\ rustonkumaini@yahoo.de
}

\begin{abstract}
The study investigates the relationship among self-confidence, motivation, and the ability of listening skill by using using 2.0. It occured when some students getting difficulty to respond listening record, they did not get any motivation while listening section is was tested to them, and practically they got less confidence to share their answer. I used mobile phone as a tool to transfer listening material, process to maintain listening class more attractive to the students. It could build up students' self confidence, motivation, and ability in listening class. Based on the implementation of listening English 2.0, the major findings were; the students felt motivated, confidence, and built up their ability where they are correlated. They feel confidence to answer questions regarding to listening material. The students felt self confidence. These findings provide a valuable framework for lecturer/instructor in English as a Foreign Language to build up those aspects by using technology $\mathbf{2 . 0}$.
\end{abstract}

Keywords: motivation; self-confidence; perceived ability; EFL; 2.0

CPendidikan Bahasa Inggris FPISH IKIP BU Malang

\section{Introduction}

In the $21^{\text {st }}$ Century, English spread out to be internationally language for many countries, including Indonesia. As a result, guideline of English as a Foreign Language (EFL) is a priority around the area which is dominantly used for academic subject. In contradictory, instructional designs have not kept to face reality. In fact, in Indonesia where there is a not surrounding areas of citizen who activate English listener-speaker, in common the language is still taught by traditional teaching instruction. Luckily, technology now offers opportunities for authentic interaction with people from other cultures that can be incorporated into the classroom (Chang \& Lehman, 2002).

This research reports the use of technology is allowed to be used pedagogically as a tool to get better understanding listening instruction as the same as English native speaker speech.
In reality, students in university almost getting hard to absorb English speech, meanwhile, they were passive to respond any questions proposed to them. Furthermore, much research has been conducted on EFL instruction with respect to effective strategies and challenges (Aliakbari \& Jamalvandi, 2010; Liu \& Jackson, 2008; Shen \& Suwanthep, 2011). First, interactive listening aspect of language learning is very urgent to a students' learning experience, but students have a little chance to listen English intensively and comprehensibility. The lack of a proper environment deprives the learners of language learning and cultural exchange opportunities, which affects their language acquisition and motivation (Kormos \& Csizer, 2007). So, it needs particular method to enhance learning motivation and self-confidence in terms of technological era. Motivation, confidence, and ability are often treated 
as distinct but related learning dimensions (Butler \& Lumpe, 2008; Clement \& Kruidener, 1985; Hirschfeld, Lawson, \& Mossholder, 2004; Philips \& Lindsay, 2006; Tavani \& Losh, 2003.

\section{LITERATURE REVIEW}

The availability of lack surrounding community of English environment outside of the classroom affects teaching and learning of English as a foreign language. When there are no English speakers easily available outside the classroom, it makes EFL learning and quality teaching more challenging (Parker, Heitzman, Fjerstad, Babbs, \& Cohen, 1995). Because of this, it needs such a mediated tool to support the challenge and opportunity to use the media which is affordable. Indeed, MALL researchers believe that the use of mobile phones for language learning might facilitate the process of language learning while possible challenges can be accommodated or alleviated (e.g., Stockwell, 2008; Stockwell. 2012; Thornton \& Houser, 2005).

\section{Mobile phones for language instruction}

Many researcher have studied use of technology to improve EFL learning (Chung, 1991; Guthrie \& Richardson, 1995; Liou, 1997; Scardamalia \& Bereiter, 1991; Van Aacken, 1999). Furthermore, the implementation of MALL is due to the learning opportunities and affordances that mobile phones would create for language learners. The use of mobile phones in language learning provides teachers and learners with substantial educational benefits, including the possibility of recording and playing audios, low costs, portability, learner friendliness, easy access, and interactivity (KukulskaHulme \& Shield, 2008; Stockwell, 2010; Wishart, 2008). Research has suggested that the use of mobile phones enables language learners to make communication with their teachers and peers more easily and conveniently. MALL researchers assert that this ease of communication with teachers and peers is a major affordance of the utilization of mobile phones for language learning (Nah, White, \& Sussex, 2008; Rosell-Augilar, 2007).

Despite potential of developing these MALL learning 2.0 opportunities for EFL, a number of EFL experts have pointed out some considerable challenges to the use of mobile phones for language learning and teaching. As Stockwell (2008) argues, one major obstacle to the use of mobile phones for language teaching is student's reluctance to use mobile phones for their educational and academic purposes. Thornton and Houser (2002) assert the small screen size of mobile phones would create another challenge to the implementation of MALL. Moreover, high cost of the use of mobile phones for educational purposes might discourage students and teachers from implementing MALL in EFL courses accordingly (Stockwell, 2007). Similarly, limited presentation of graphics of mobile phones may act as another impeding factor (Albers \& Kim, 2001).

Alternatively, MALL researchers believe that the use of mobile phones could immediately facilitate the process for language learning while possible challenges can be accomodated or alleviated (e.g., Stockwell,. 2008; Stockwell. 2012; Thornton \& Houser, 2005. Stockwell (2012) maintains that new technologies are emerging while new types of practical constraint might appear. Unavoidably, as stcokwell (2012) points out, "mobile learning will continue to take on new shapes and forms as it becomes more familiar to both teachers \& learners” (p.30). 


\section{Motivating EFL Learners with 2.0 Technology}

Jones (2001) asserts that both EFL teachers and students should have positive attitudes toward MALL for its successful implementation. Motivation improves or declines as the consequence of positive or negative learning experiences that motivate or demotivate the students (Sakai \& Kikuchi, 2009). For EFL learners, it means that bringing out their experiences, drive students' level of motivation both in and out of the classroom.

An increasing number of researchers have investigated the use of mobile devices for language learning (Kiernan \& Aizawa, 2004; Thornton \& Houser, 2005). Personal learning via mobile devices can motivate students to learn, while supporting social contact and collaborative learning, both of which are crucial to language learning (Kukulska-Hulme \& Shield, 2008). Dornyei process model of motivation (Dornyei, 2000, 2001) and his theory of motivational self-system (Dornyei, 2005) provides a framework that stresses the importance of the self-concept of the language learner and suggest that motivation stems from the desire to lessen the dichotomy between one's actual self, and the self one wishes to become.

\section{Motivation, Confidence, and Ability as learning dimensions}

Motivation, confidence, and ability are often treated as distinct but related learning dimensions (Butler \& Lumpe, 2008; Clement \&Kruidenier, 1985; Hirscfeld, Lawson, \& Mossholder, 2004; Philips and Lindsay, 2006; Tavani \& Losh, 2003). The literature widely expose motivation, confidence, and ability are directly related to one another. It also impacts each other and that if one factor increases and decreases, the other will automatically follow in a direct relationship. All tree learning dimensions are the result of cumulative experiences of the student, both in and out of the classroom. All tree dimensions improve or decline any positive or negative experiences of the consequence.

\section{Scaffolding to promote active learning}

In designing instructional design in classroom material, i incorporated authentic video sources with intriguing issue on the recent time which is attractive to be discussed. The material is combined with some interactive questions to be answered in a group that consisting a group leader; he is minimally able to absorb listening material and help another teammates to conduct cooperative discussion in a short time. This process of teaching and learning helps to maintain students' awareness to handle their autonomous listening activity alive. Scaffolding is a teaching and learning model for classroom interaction in which the teacher initially gives a high level of support to the student, such as availability to translate during interaction in the foreign language, with support slowly withdrawn to help the student become more independent (Beed, Hawkins, \& Roller, 1991).

\section{Importance of students' perception}

The view of English as foreign language listener has been tremendously changed all the time, by many factors. In order to know the effectiveness of using 2.0 technology for EFL listening instruction, I need to either use the students' perception, or external measurements. Various studies have linked learner's perception such as selfefficacy, his / her beliefs with language learning processes and outcome (i.e, Dornyei, 2005; Hosseini \& Pourmandnia, 2013; Lotfi, 2012). Moreover, there is abundant research showing that students' perceptions of 
their own motivation, confidence, and ability accurately predict a variety of learning factors, including goal orientation, self-efficacy and actual outcomes (Bandura, 1989; Hardre \& Sullivan, 2008; Kaplan \& Midgley, 1997; Leach \& Queirolo, DeVoe \& Chemers, 2003; Noels, Pelltier, Clement \& Vallerand, 2003; Ryan \& Deci, 2000; Wolters \& Pintrich, 1996). The framework of learning processes versus learning outcomes hand in hand with positive self-perception and selfefficacy. It will benefits for learning goals and lead to vigorous outcomes as well. In particular, a "learning orientation", in which individual are concerned about developing their ability and their focus is on gaining understanding, insight, and skill, is linked to integrative motivation and thus positive outcomes (Brunin, Schraw, \& Ronning, 1999). This socialpsychological understanding of the student, encompassing self-efficacy versus anxiety and based on experiences in and outside the classroom, has been found to particularly valuable in describing the EFL classroom dynamic (Clement, Dornyei, \& Noels, 1994). Therefore, the student perception in ability, motivation, and confidence may not earn extensive evaluation rather than perceiving worthy in term of students' effort on actual ability outcome.

\section{Purpose of the study}

The review of the literature suggested that further empirical research was needed into how technology 2.0 can be used in the EFL classroom and producing reaction fo the students. Furthermore, it will provide more information and manual guidance to educators who wish to implement student centered learning (SCL) to improve learning quality and atmosphere. The main purposes of this empirical study are: (1) Which learning dimensions ( Motivation, Confidence, and Ability) changed the most to the students perceptions due to listening 2.0 MALL; (2) the relationships among the three learning dimensions; (3) and which dimension best predicted English listening ability as perceived by students. This practical perspective of educators would be valuable to good final result. In addition, the students who are well engaged in listening ability during a semester will support self-learning practice both educator and students in EFL context. In sum, students are more motivated by this instruction and give lot of contribution to the development of listening instructional design in 2.0 in the next years.

\section{Instructional Design}

This study apply the use of technology in helping students to practice specific listening information easier to absorb. This practical method used to bridge the gap among students in this area. The instruction was given to maintain good relationship among students in building their confidence, ability, and motivation during the listening class with 2.0 technology.

Listening 2.0 was held during odd semester in third semester at listening III class taught by me. Some preparation have already completed with such instructional design considering the some factors which have mentioned; the topic has taken from various news around the world which attracting students to re-inform and gave opinion about it. Some questions arranged to interest students deliver their idea and opinion by listening to regarding to the issue happen in the news.

\section{Listening 2.0 methods}

The development of listening instruction using MALL is divided becoming two major steps. Table 1 
containing Pre activity done by students as follow:

The first major step is students divided into several group which lead by a single expert student. Next, the students were given a video containing trend issues through Whatsapp application that they need to listen carefully. Some difficult notes regarding to the material should be discussed and negotiated by teammates. Students should make critically questions related to the video which concerning to $\mathrm{C} 1, \mathrm{C} 2$, C3, C4. After that, they should make language observation-pronunciation, encoding processes; the reporter asks some relevant questions connecting to the news. Afterwards, groups would have 30 minute discussion and negotiating, 5 minutes for presentation, 1 minutes for critique related to questions made by per group.

Table 1- Sequence of each lesson listening III 2.0 MALL

\begin{tabular}{|l|c|c|}
\hline \multicolumn{1}{|c|}{ Phases Lecturer } & Student \\
\hline $\begin{array}{l}\text { Making with a } \\
\text { team wisu } \\
\text { leader. }\end{array}$ & & $\bullet$ \\
\hline $\begin{array}{l}\text { Trend } \\
\text { video. }\end{array}$ & $\bullet$ \\
\hline $\begin{array}{l}\text { Downloading the } \\
\text { video }\end{array}$ & & $\bullet$ \\
\hline $\begin{array}{l}\text { Giving the video } \\
\text { through WA. }\end{array}$ & $\bullet$ & $\bullet$ \\
\hline $\begin{array}{l}\text { Listening to the } \\
\text { video }\end{array}$ & & $\bullet$ \\
\hline $\begin{array}{l}\text { Noting difficult } \\
\text { vocabularies }\end{array}$ & & $\bullet$ \\
\hline $\begin{array}{l}\text { Discussion and } \\
\text { negotiation. }\end{array}$ & & $\bullet$ \\
\hline $\begin{array}{l}\text { Making C1-C4 } \\
\text { Questions by } \\
\text { team }\end{array}$ & $\bullet$ & $\bullet$ \\
\hline $\begin{array}{l}\text { Observation } \\
\text { sheet. }\end{array}$ & & \\
\hline $\begin{array}{l}\text { Discussion } \\
\text { session within } \\
\text { group. }\end{array}$ & & $\bullet$ \\
\hline
\end{tabular}

\begin{tabular}{|l|l|l|}
\hline $\begin{array}{l}\text { Critical question } \\
\text { raised by another } \\
\text { team. }\end{array}$ & $\bullet$ & $\bullet$ \\
\hline & & \\
\hline
\end{tabular}

\section{Methodology}

I use quantitative methodology to look out about changes of students' perception in their motivation, confidence, and ability as a result of implementing MALL 2.0 technology in Listening class.

The study measured students' perception during the listening class at odd semester, based on feedback and grades which i received from my students to meet with the criteria $\mathrm{i}$ proposed to them in the end of the semester. The discussion and critical session were looked as a source of authentic method of assessment to earn the goal of this instruction as well. Research has shown that older adolescents, such as those who participated in this study, are able to know and to report accurately their present achievement and to accurately predict future learning outcomes (Berk, 2003; Linnenbrink \& Pintrich, 2002). Indeed, I assumed that self-reporting was a valid methodology because the students were well welcomed to commenting and participating in receiving classroom grades and personalized lecturer feedback in listening III class. Furthermore, motivation and confidence are external aspect that are hardly to measure.

\section{Quantitative methodology}

Survey research design are procedures in quantitative research in which investigators administer a survey to a sample or to the entire population of people to describe the attitudes, opinions, behaviors, or characteristic of the population (Creswell, 2008). The decision to divide instruments 
composition based on the three sections are motivation, ability, and confidence, then analyze them individually, the three learning dimensions were treated distinctively and separately but still connecting to one another referring to findings of related literature.

The surveys were divided into several dimension of learning, they were student motivation, ability, and ability. These dimensions also added by student interest and student confidence then changes in student perception in changes about motivation, ability and confidence. Furthermore, there were 13 items portrayed about the degree of change in student interest to study listening English 2.0 MALL besides changes in motivation about changes in targetting listening 2.0. The second section, there were 11 items dealing with the change the students perceived in their listening III proficiency level. There were 11 questions regarding to student confidence in listening English. The final section was student experience using technology and students' demographic information about gender, age, experiences of learning English. The scoring criteria were considered into a five point scale assessed student perceptions regarding changes in motivation, ability, and confidence as a result of using 2.0 technology. Next, the low end of the scale was labeled into $(=1.00)$ as a "significantly reduced", and the high end of the scale was labeled "significantly increased" (=5.00). The midpoint of the scale $(=3.00)$ was labeled "no change."

I also organized the survey instrument to the 45 students in odd semester at the end of English listening material. The data collection was submitted in the end of the semester. The survey comprised four major sections that developed by me based on the review of the related literature, including items taken from Gardner and Lambert's questionnaire (1972). The survey was addressed to 45 students. The internal reliability for the instrument is 92 with each section scoring above 85 which is considered to have high reliability compared with the minimum Cronbach a 0f. 75. Which is considered reliable.

I chose multiple regression and factor analysis as the main methodologies (in addition to descriptive statistics) in order to get completely understanding about students' perception on motivation, confidence, and ability.

SPSS version 15 was used for analyzing the data, especially frequencies, means, reliability, factor analysis, Pearson product-moment correlation, and stepwise multiple regressions.

\section{Findings}

Changes in three variables due to the frequency of listening 2.0

To determine the effect of 2.0 technology in English listening class on the students' perception of their own ability, confidence, and motivation, the mean score of computation was calculated at the end of third semester. The analysis revealed that the participants showed moderate increase in their perceived motivation only with a mean score increasing from 3.80 to 4.09 .

\section{Relationship among the motivation, ability, and confidence}

To examine the relationships among the three dimensions, the Pearson-correlation coefficient need to be calculated. The three learning dimensions positively correlated with one another at the 0.1 level while confidence had the strongest relationship with ability, with coefficient of 679, indicating that confidence was a more reliable predictor of ability than motivation. 


\section{Critical elements of perceived confidence and motivation predicting perceived English ability}

Exploratory factor analysis

In order to decrease the number of the components (factors) in each of three dimensions- motivation, ability, and confidence, a factor analysis was performed, using a principal-axes method with varimax rotation. The analysis revealed an underlying pattern of relationship in each dimension so that the items could be reduced, thus forming several factors. A Kaiser-Meyer-Oklin (KMO measure of the sample adequacy was to determine the fitness of the data prior to further analysis. The decision to perform a factor analysis was based on a factor loading of 0.4 or higher and an eigenvalue greater than 1 .

Factor analysis of motivation

The varimax rotation solution for Motivation revealed that $61.669 \%$ of the variance was explained by the four factors, with component 1 , use of media and technology, contributing 20.610\%; component 2, the social interaction, contributing 15.638\%; component 3, cultural understanding

\begin{tabular}{|l|l|l|l|}
\hline Factor & $\begin{array}{l}\text { Rotat } \\
\text { ed } \\
\text { factor } \\
\text { leadi } \\
\text { ng }\end{array}$ & $\begin{array}{l}\text { Of } \\
\text { varian } \\
\text { ce }\end{array}$ & $\begin{array}{l}\text { Question } \\
\text { items }\end{array}$ \\
\hline .742 & & $\begin{array}{l}\text { Your } \\
\text { motivation } \\
\text { to study } \\
\text { English } \\
\text { listening? }\end{array}$ \\
\hline & .659 & $\begin{array}{l}\text { To listen } \\
\text { to English } \\
\text { more often }\end{array}$ \\
\hline & $\begin{array}{l}.614 \\
\text { Your } \\
\text { desire to } \\
\text { understand } \\
\text { the news? }\end{array}$ \\
\hline
\end{tabular}

\begin{tabular}{|c|c|c|c|}
\hline & .554 & & $\begin{array}{l}\text { Your } \\
\text { desire to } \\
\text { be } \\
\text { included } \\
\text { in } \\
\text { relationshi } \\
\text { ps with } \\
\text { others who } \\
\text { use } \\
\text { English? }\end{array}$ \\
\hline \multirow[t]{7}{*}{ Factor 1} & .423 & 20610 & $\begin{array}{l}\text { Your } \\
\text { motivation } \\
\text { to listen } \\
\text { English / } \\
\text { watch } \\
\text { radio /TV } \\
\text { program? }\end{array}$ \\
\hline & .784 & 15.638 & $\begin{array}{l}\text { Your } \\
\text { desire to } \\
\text { study } \\
\text { abroad? }\end{array}$ \\
\hline & .745 & & $\begin{array}{l}\text { Your } \\
\text { desire to } \\
\text { try to use } \\
\text { English } \\
\text { through } \\
\text { different } \\
\text { channels }\end{array}$ \\
\hline & .523 & & $\begin{array}{l}\text { Your } \\
\text { interest in } \\
\text { your } \\
\text { Listening } \\
\text { material? }\end{array}$ \\
\hline & .827 & 12.734 & $\begin{array}{l}\text { Your } \\
\text { motivation } \\
\text { to } \\
\text { encounter } \\
\text { Listening } \\
\text { MALL? }\end{array}$ \\
\hline & .577 & & $\begin{array}{l}\text { Your } \\
\text { understand } \\
\text { ing of } \\
\text { Listening } \\
\text { MALL? }\end{array}$ \\
\hline & .858 & 12.687 & $\begin{array}{l}\text { Your } \\
\text { interest in } \\
\text { Listening } \\
\text { what topic } \\
\text { through }\end{array}$ \\
\hline
\end{tabular}

Available online at: http://ejurnal.budiutomomalang.ac.id/index.php/journey 


\begin{tabular}{|l|l|l|l|}
\hline & & & MALL? \\
\hline & .582 & $\begin{array}{l}\text { Your } \\
\text { interest in } \\
\text { discussing } \\
\text { topic? }\end{array}$ \\
\hline & .553 & & $\begin{array}{l}\text { Your } \\
\text { motivation } \\
\text { to } \\
\text { converse } \\
\text { with } \\
\text { foreigners } \\
\text { by using } \\
\text { English } \\
\text { translator? }\end{array}$ \\
\hline $\begin{array}{l}\text { Tronbac } \\
\text { h's } \\
\text { alpha } \\
\text { value }\end{array}$ & & 61.669 & .85 \\
\hline
\end{tabular}

Factor analysis of perceived ability

\begin{tabular}{|l|l|l|l|}
\hline Factor & $\begin{array}{l}\text { Rotat } \\
\text { ed } \\
\text { factor } \\
\text { leadi } \\
\text { ng }\end{array}$ & $\begin{array}{l}\text { Of } \\
\text { varian } \\
\text { ce }\end{array}$ & $\begin{array}{l}\text { Question } \\
\text { items }\end{array}$ \\
\hline Factor 1 & .812 & 22.684 & $\begin{array}{l}\text { Understan } \\
\text { d English } \\
\text { with } \\
\text { Indonesian } \\
\text { ? }\end{array}$ \\
\hline & .774 & $\begin{array}{l}\text { Understan } \\
\text { d English } \\
\text { you hear } \\
\text { in media? }\end{array}$ \\
\hline & $\begin{array}{l}.720 \\
.809\end{array}$ & 19.802 & $\begin{array}{l}\text { Use } \\
\text { translator } \\
\text { tool? }\end{array}$ \\
\hline $\begin{array}{l}\text { Listening } \\
\text { English } \\
\text { pronunciat } \\
\text { ion well? }\end{array}$ \\
\hline & $\begin{array}{l}\text { Listening } \\
\text { English } \\
\text { with your } \\
\text { lecturers? }\end{array}$ \\
\hline & $\begin{array}{l}\text { Understan } \\
\text { d English }\end{array}$ \\
\hline
\end{tabular}

\begin{tabular}{|l|l|l|l|}
\hline & & & accent? \\
\hline & .414 & $\begin{array}{l}\text { Comprehe } \\
\text { nd English } \\
\text { listening? }\end{array}$ \\
\hline & .801 & 15.103 & $\begin{array}{l}\text { Understan } \\
\text { d English } \\
\text { with } \\
\text { native } \\
\text { speakers? }\end{array}$ \\
\hline & .730 & & $\begin{array}{l}\text { Listening } \\
\text { English } \\
\text { with } \\
\text { foreigners } \\
\text { ? }\end{array}$ \\
\hline $\begin{array}{l}\text { alpha } \\
\text { value }\end{array}$ & .710 & 12.257 & $\begin{array}{l}\text { Understan } \\
\text { d native } \\
\text { speaker } \\
\text { idiom or } \\
\text { slang? }\end{array}$ \\
\hline Total & & 70.186 & $\begin{array}{l}\text { Listening } \\
\text { English } \\
\text { with your } \\
\text { peers? }\end{array}$ \\
\hline & .511 & & \\
\hline & & & \\
\hline
\end{tabular}

Factor analysis of perceived confidence

\begin{tabular}{|l|l|l|l|}
\hline Factor & $\begin{array}{l}\text { Rotat } \\
\text { ed } \\
\text { factor } \\
\text { leadin } \\
\text { g }\end{array}$ & $\begin{array}{l}\text { Of } \\
\text { varian } \\
\text { ce }\end{array}$ & $\begin{array}{l}\text { Question } \\
\text { items }\end{array}$ \\
\hline Factor 1 & .773 & 25.338 & $\begin{array}{l}\text { Listening } \\
\text { English } \\
\text { with } \\
\text { foreigner } \\
\text { s? }\end{array}$ \\
\hline & .711 & & $\begin{array}{l}\text { Use } \\
\text { MALL? }\end{array}$ \\
\hline & .685 & & $\begin{array}{l}\text { Listening } \\
\text { English } \\
\text { through } \\
\text { mobile }\end{array}$ \\
\hline
\end{tabular}

Available online at: http://ejurnal.budiutomomalang.ac.id/index.php/journey 


\begin{tabular}{|c|c|c|c|}
\hline & & & phone? \\
\hline & .651 & & $\begin{array}{l}\text { Think } \\
\text { about } \\
\text { study } \\
\text { abroad }\end{array}$ \\
\hline & .608 & & $\begin{array}{l}\text { Think } \\
\text { about } \\
\text { traveling }\end{array}$ \\
\hline & .514 & & $\begin{array}{l}\text { Listening } \\
\text { English } \\
\text { generally } \\
\text { ? }\end{array}$ \\
\hline & .426 & 18.333 & $\begin{array}{l}\text { Hear } \\
\text { English } \\
\text { spoken } \\
\text { by } \\
\text { Indonesia } \\
\text { n? }\end{array}$ \\
\hline & .811 & & $\begin{array}{l}\text { Hear } \\
\text { English } \\
\text { spoken } \\
\text { by native } \\
\text { speakers? }\end{array}$ \\
\hline & .673 & 17.927 & $\begin{array}{l}\text { Listening } \\
\text { English } \\
\text { with your } \\
\text { lecturers? }\end{array}$ \\
\hline & .879 & & $\begin{array}{l}\text { Listen or } \\
\text { speak } \\
\text { English }\end{array}$ \\
\hline & .834 & & $\begin{array}{l}\text { Listening } \\
\text { English } \\
\text { with } \\
\text { other } \\
\text { students? }\end{array}$ \\
\hline & & & \\
\hline Total & & 61.598 & \\
\hline $\begin{array}{l}\text { Cronbac } \\
\text { h's alpha } \\
\text { value }\end{array}$ & & .89 & \\
\hline
\end{tabular}

The same technique was to predict the factor 1, listening skills. The individual terms showed that confidence factor 1, interaction skill, had the strongest association linked to listening skills in perceived ability. All the simultaneous regressions had statistically significance, and variance explained of these models was $27.2 \%, 30.8 \%, 34.7 \%$, respectively for model $1,2,3$. The regression equation is as following.

Ability $1=342 \mathrm{x}$ confidence $\_1+.227 \mathrm{x}$ confidence_3+.208x motivation_3

\section{Discussion}

The scope of this intentional study was to gather any information which could be of practical use to lecturers to go from traditional or teacher centered to student centered of memorization instructional design. Even though the findings shows the validation the general concept of student-centered instruction, the truly value of this study emphasizes the findings on interaction as a tool for listening learning.

The findings simultaneously reveal the Confident facet of interaction skills played a significantly role in the students' perceptions of their ability. The students' confidence in their listening class linked more closely than any factors to their opinion about listening, speaking, writing ability. In the same way, in the qualitative interviews, the students helped by the interaction made by the lecturer using attractive instructional design by the 2.0 technology.

Many of them were vigorously listening to the material through 2.0 technology and made them associate discussing the information from it then provided into a class altogether. The participation of the students were high enough to get in touch with instructions which has been given since pre activity hold.

The 2.0 technology significantly influenced learning atmosphere to improve their self confidence, motivation, and ability into the class. In addition, this activity would aid them to be individually better to enhance their 
listening performance. In short, I absolutely believe that the technology fully assisting them to well improved learning quality and directing them to be autonomous learners.

\section{The importance of motivation}

Even though confidence predicted to be best merit of students' perception of increasingly English ability, motivation even so played a crucial role. Over the academic year subject, the students' mean score in their understanding of motivation increased comparing to two others dimensions. Thus, then students did feel pleasant listening to English and they felt better in using 2.0 technology MALL after they several sessions of interacting by using it. The most striking fact is they had more attracted to learning and using $M A L L$ in listening English in various instructions. The video which appeared on screen on mobile phone is very helpful to the students. The more the learners feel enjoyable to interact with 2.0, the more likely they were to feel high motivation. Therefore, it increases their evaluation of their own confidence or ability along with the more frequency of using it.

\section{Interaction and discussion during listening 2.0}

The findings of the study is to highlight the need for multiple facets on the value of access to MALL in listening English. The interaction using technology is unavoidable for those who think that it will support students' autonomous learning process in this era. Interaction and discussion is merely the process of good negotiation towards shaping students learning habit and competence. Furthermore, comprehensible input, negoitation of meaning, and comprehensible output can be achieved effectively through MALL activities, as these features of mobile phones can provide language learners with comprehensible input through preprogrammed software, via internet searching (Nah; White; Sussex, 2008)

\section{Conclusion}

Teaching listening by using 2.0 technology is more comfortable and interesting as student centered role in this decade. EFL listening classroom shows that instructional methodology pushing attractive interaction among the students in building self confidence as an ultimate goal of listening learning process.

Coincidental comment was released by a student to actively participating in the dynamic interaction which incorporating technology 2.0 at teaching learning instruction.- regular interaction by using 2.0 technology / MALL with friends are helpful to maintain "a habit” in listening English. The findings suggest that language educator should enclose interactive instructional design in their curriculum design. While, using formal and informal setting are permissible to cover interactive learning by 2.0 technology within the design itself. In addition, introducing 2.0 technology is unavoidable as a medium of learning scaffolding process. The integration between 2.0 technology and interactive instructional design will result independent students who are confident to engage their participation in learning listening.

This study also suggest that foreign language educators should try to give more interaction toward the listening process in their class. In order to complete this, the English listening teachers should natural setting of native speakers' conversation in students' activity to be dynamic in learning process. Finally, the activity will automatically help the students boosting their confidence and motivation. 
The ultimate goal of this activity is merely to provide scaffolding process from which the students could enhance and continoue their own learning. This study shows that instructional design combining with the use of 2.0 technology help the students to scaffold the material in both formal and informal setting. It allows the students becoming well-engaged in the process of decoding the listening processes. As shown by the data, even though the students were far from the authentic interaction, they were able to show their motivation by actively participated in their surrounding area. Furthermore, Mishra and Koehler (2006) suggest, the simultaneous improvement of teacher's technological, pedagogical, and content (language proficiency for language teachers) competence can help them use technology for teaching purposes efficiently. Considering from these aspects, teaching and learning are closely enough to the use of technology as part of interactive method in class.

\section{REFERENCES}

Berk, L. E. (2003). Development through the lifespan. New York: Pearson.

Butler, K., \& Lumpe, A. (2008). Student Use of Scaffolding Software: Relationships with Motivation and Conceptual Understanding. Journal of Science Education \& Technology, 17(5), 427-436. doi:10.1007/s10956-008-9111-9.

Beed, P. L., Hawkins, E. M., \& Roller, C. M. (1991). Moving learners toward independence: The power of

scaffolded instruction. Reading Teacher, 44(9), 648-655.

Brunin, R. H., Schraw, G. J., \& Ronning, R. R. (1999). Cognitive psychology and instruction (3rd ed.). Upper Saddle River, NJ: Prentice-Hall.

Butler, K., \& Lumpe, A. (2008). Student Use of Scaffolding Software: Relationships with Motivation and Conceptual Understanding. Journal of Science Education \& Technology, 17(5), 427-436. doi:10.1007/s10956-008-9111-9.

Chang, M. M., \& Lehman, J.D. (2002).

Learning foreign language through an interactive multimedia program: An experimental study on the effects of the relevance component of the ARCS model. The CALICO Journal, 20(1), 81-98.

Clément, R., Dörnyei, Z., \& Noels, K. A. (1994). Motivation, selfconfidence, and group cohesion in the foreign language classroom. Language Learning, 44(3), 417-448.

Cohen, A. D. (1995). The role of language of thought in foreign language learning. Working Papers in Education, 11, 1-23

Csizer, K. And Kormos, J (2008) The relationship of intercultural contact and language learning motivation among Hungarian students of English and German. Journal of Multilingual and Multicultural Development 29 (1), 30-48.

Dornyei, Z. (2005). The psychology of the language learner: Individual differences in second language acquisition. Mahwah, NJ: Lawrence Erlbaum Associates.

Guthrie L. F., \& Richardson, S. (1995). Turned on to language arts: Computer literacy in primary grades. Educational Leadership, 53(2), $14-17$.

Thornton, P. and Houser, C. (2005) Using mobile phones in English education in Japan. Journal of 
Computer Assisted Learning, 21(3): 217-228.

Jones, J. (2001). CALL and the responsibilities of teachers and administrators. ELT Journal, 55(4), 360-370.

Kiernan, P. J. and Aizawa, K. (2004)

Cell phones in task based learning - are cell phones useful language learning tools? ReCALL, 16(1): 71-84.

Kikuchi, K. (in press). Listening to our learners' voices: What demotivates EFL high school students? Language Teaching Research, 13(4).

Kukulska-Hulme, A. (2007). Mobile usability in educational contexts: What have we learnt? The International Review of Research in Open and Distance Learning, 8.

Liou, H. C. (1997). The impact of WWW texts on EFL learning. Computer Assisted Language Learning, 10(5), 455-478.

Mishra, P., \& Koehler, M. (!"'+). Technological pedagogical content knowledge: A framework for teacher knowledge. !e Teachers College Record, 108(6), 1017-1054

Nah, K. C., White, P. and Sussex, R. (2008) The potential of using a mobile phone to access the Internet for learning EFL listening skills within a Korean context. ReCALL, 20(3): 331347.

Stockwell, G. (2007). Vocabulary on the move: Investigating an intelligent mobile phonebased vocabulary tutor. Computer Assisted Language Learning, 20(4), 365383.

Stockwell, G. (2008). Investigating learner preparedness for and usage patterns of mobile learning. ReCALL, 20(3), 253270.

Stockwell, G. (2012). Commentary: Working with constraints in mobile learning - A response to Ballance. Language Learning \& Technology, 16 (3), 24-31.

Thorton, P., \& Houser, C. (2002). Mlearning in transit. In P. Lewis (Eds.), The changing face of CALL (pp. 229-243). Lisse, The Netherlands: Swets and Zeitlinger. 